\title{
Aproximación á toponimia das freguesías de Arante, Cedofeita, Couxela, Covelas, A Devesa e Ove do concello de Ribadeo: núcleos habitados
}

\author{
Rocio Dourado Fernández \\ Instituto da Lingua Galega (ILG) / Universidade de Santiago de Compostela (USC)
}

\begin{abstract}
Resumo:
Este traballo trata unha serie de topónimos maiores procedentes de seis das doce freguesías do concello de Ribadeo (Lugo). O obxectivo é realizar un estudo etimolóxico-lingüístico do material reunido (108 topónimos) co fin de ofrecer unha explicación das estruturas toponímicas aplicadas na denominación da realidade física circundante.
\end{abstract}

Palabras chave:

Toponimia, lingüística histórica, onomástica, etimoloxía.

\begin{abstract}
:
This paper treats a series of major proceeding toponyms from six of the twelve parishes of municipality of Ribadeo (Lugo). The aim is to carry conduct an etymological and linguistic study of the gathered material (108 toponyms) with the objective of offering an explanation of the typonimical structures wich give name to the circundant physical reality.
\end{abstract}

Key words:

Toponymy, historical linguistics, onomastics, etymology.

\section{Introdución}

O concello de Ribadeo está situado no extremo nororiental da provincia de Lugo (Galicia). Testa polo norte co mar Cantábrico, polo leste coa ría de Ribadeo, polo oeste co concello de Barreiros e polo sur co concello de Trabada. Segundo a última división comarcal ${ }^{1}$ levada a cabo pola Xunta de Galicia, Ribadeo forma parte da bisbarra da Mariña Oriental, que integra precisamente xunto cos municipios de Barreiros, Trabada e A Pontenova.

1 Tomamos como referencia a división comarcal oficializada pola Xunta de Galicia mediante o Decreto 65 / 1997 do 20 de febreiro de 1997 e consultábel no seguinte web: http://www.comarcasdegalicia. com/archivos/textoslegales/3_mapa.pdf. 
Do punto de vista histórico, Ribadeo naceu como vila de reguengo, vinculada ao proceso de repoboación urbana do litoral cantábrico. Obtivo unha carta puebla do rei Fernando III (López Alsina 1976: 130), e a partir da segunda metade do s. XIV pasou a se converter nun concello de señorío laico, ao se lle conceder en propiedade a Pierre de Villaines. Foi, xunto con Viveiro e Mondoñedo, unha das tres entidades urbanas xurdidas no norte da actual provincia de Lugo ao longo da Idade Media. De feito, durante un breve intervalo de tempo (concretamente entre 1182 e 1224) chegou a albergar a sé episcopal mindoniense. O desenvolvemento que alcanzou o seu porto situou a vila de Ribadeo á cabeza do comercio xerado nos portos do Cantábrico, primacía que ostentou até a súa decadencia, xa no s. XIX.

Canto á natureza e enfoque deste traballo, cómpre dicir que consiste na análise etimolóxica das denominacións dos núcleos habitados que compoñen seis das doce freguesías do devandito concello: Arante, Cedofeita, Couxela, Covelas, A Devesa e Ove. Trátase, pois, do extracto dun traballo máis amplo e exhaustivo que se está a desenvolver nestes momentos e que abrangue o estudo global da toponimia do devandito concello mariñao.

Ao estarmos perante toponimia maior, o Nomenclátor de Galicia será a fonte principal de onde extraiamos as denominacións oficiais de todos eles, que serán as que tomemos como referencia para o noso estudo, mais realizando os comentarios e observacións pertinentes sempre que existiren alteracións (quer na realización fonética dos topónimos por parte dos falantes, quer en aspectos doutro tipo) con respecto ás formas recollidas no devandito repertorio.

\section{Corpus de núcleos habitados e estudo}

\subsection{ARANTE (San Pedro)}

O nome da parroquia aparece como ecclesia Santi Petri de Alanti nun documento do ano 935, e coa forma Arante en diplomas posteriores con data de 1305, 1351 e 1371, entre outros. Bascuas (2002: 30) descarta que se trate do descendente do xenitivo do antropónimo galo ALANTIUS (orixe do francés Alençon), que encaixaría coa variante máis antiga atestada mais que careceu de difusión na Península Ibérica. Deste xeito, o dito autor decántase por entender Alanti como erro paleográfico ou alteración fonética de difícil explicación, e prefire reconstruír a etimoloxía do topónimo a partir da variante máis abundante, ou sexa Arante.

Poderiamos falar así dun hidrotopónimo baseado no indoeuropeo *er- 'fluír, moverse' a través dunha variante *ar- á que se lle engade o coñecido sufixo -nt- (precedido 
neste caso de vogal presufixal - $a$-), conforme a un esquema morfolóxico frecuente en topónimos de orixe antigo-europea. Para Bascuas (2002: 169), habería que considerar unha secuencia sufixal -ante presente tamén en topónimos como Amarante, Serantes e similares. De todos os xeitos, o mesmo tema *arant- témolo tamén en topónimos galegos como Arantón, Arantei e similares, de clara fasquía prerromana. Por outra banda, a prol da opción hidronímica está a existencia do río francés Arante.

Dentro da freguesía de San Pedro de Arante atopamos os seguintes núcleos de poboación:

2.1.1. Barredal, O: Debe tratarse dun derivado do substantivo común barro 'arxila', 'masa que resulta da mestura de terra e auga', 'masa branda que se forma ao chover' (Ir Indo, s.v. barro). A ese apelativo deberon engadírselle en fases sucesivas dous sufixos como son -edo (< latín -ĒTǓ) e -al (< latín -ĀLE), expresando unha idea abundancial. De feito, a fase intermedia barredo aparece como topónimo (Barredo é nome dunha freguesía de Castroverde, e tamén temos As Barredas en Monforte de Lemos), e Eladio Rodríguez recólleo como apelativo con significados como "Lugar donde hay o se forma mucho barro" ou "En los valles lucenses de Lemos, Quiroga y Sarria llaman barredos a unas formaciones margosas y arcillosas muy desenvueltas, que en aquella gran cuenca existen en capas horizontales pertenecientes al terreno secundario, según los geólogos" (DEGC). De feito, este mesmo autor dá a forma barredal como sinónimo de barredo. Canto á base barro, trátase con toda probabilidade dun termo prerromano, se ben os autores vacilan á hora de asignalo a un estrato lingüístico concreto. Coromines ( $D C E C H$, s.v. BARRo) pensa nunha orixe céltica. O substantivo barro é ben coñecido como sinónimo de lama, sendo cuantitativamente moito máis empregado este último na lingua oral da zona, a diferenza do que ocorre co rendemento toponímico de barro, cuxos derivados se revelan como máis abondosos.

2.1.2. Bestilleiros, Os: Carré Alvarellos ( $D G C V$ ) aboa a voz bestilleiro como "Ballestero, soldado que usa ballesta", indicando que se trata dun arcaísmo. De aceptarmos a vinculación do topónimo con este substantivo, poderiamos explicar a denominación do lugar pola existencia no mesmo dalgún tipo de destacamento militar en época medieval. Por outra banda, a forma documéntase como apelido persoal tanto na actualidade como no período medieval (Pedro Bestileyro 1261) $)^{2}$, co cal tampouco deberiamos descartar que o nome de lugar teña esa orixe, atendendo ademais a que aparece flexionado en plural.

2 Agás cando indiquemos expresamente o contrario, as formas medievais empregadas nesta contribución foron extraídas sempre do Tesouro Medieval Informatizado da Lingua Galega (TMILG), dirixido por Xavier Varela Barreiro (véxase bibliografía). 
Outra opción en principio máis remota sería relacionar o derivado bestilleiro co zoónimo besta (< latín BESTǏA), a través dun hipotético derivado non documentado *BESTǏCǓLA ( $>$ *bestella). A adición do sufixo -eiro (< latín -ĀRIUU) completaría esta explicación, que implicaría en calquera caso a pechazón da vogal pretónica $(*$ bestelleiro $>$ bestilleiro) por efecto do ditongo decrecente tónico e/ou da consoante palatal $[K]$ subseguinte. De todos os xeitos, trátase dunha alternativa meramente conxectural.

2.1.3. Cei: A xulgar pola estrutura, debe tratarse dun antrotopónimo, se ben carecemos de atestacións documentais que nos permitan determinar cun mínimo de fiabilidade cal foi o nome persoal que xerou esta denominación toponímica. Unha posíbel hipótese é que proceda da forma de xenitivo do antropónimo latino CAELIŬS documentado para o topónimo Cenlle baixo variantes como Ceeli, Çelle ou Çeenlle, tratándose, deste xeito, dunha variante diverxente do mesmo étimo CAELII $>$ ${ }^{*}$ Celi $(i)>*^{*}$ Celi $>$ Cei.

2.1.4. Cima de Vila: Topónimo alusivo á posición elevada do núcleo de poboación en cuestión. O substantivo cima 'cumio, parte máis alta' procede co latín CYMA, que presentaba o mesmo significado. Pola súa banda, o modificador vila remite ao latín Uīlla, de presenza abundantísima na nosa toponimia, sobre todo en combinación con xenitivos de antigos nomes de posesor.

2.1.5. Fondo de Vila: Estamos perante un topónimo replicante do anterior, pois alude á posición máis baixa do núcleo ao que dá nome. O substantivo fondo remite ao latín FǓNDŪS 'fondo'.

2.1.6. Fornos, Os: Forma de plural do substantivo forno, procedente á súa vez do latín FǓRNǓs 'forno'. Na documentación medieval galega, a estancia en que se encontraba o forno, polo xeral unha construción independente e externa á casa, aparece mencionada baixo formas como furnus e forno (Varela Sieiro 2008: 213214). De todos os xeitos, segundo Álvarez Maurín (1994: 105), tampouco cómpre descartar que cando menos algúns destes topónimos baseados no latín FǓRNǓs sexan "aplicaciones metafóricas que comparan la orografía del terreno con la construcción de forma abovedada que designa el término latino furnum".

2.1.7. Madanela, A: Forma popular do hebraico Magdalena, á súa vez xentilicio de Magdala, nome dunha localidade palestina que parece remontar ao hebraico migdal 'torre' (Rivas Quintas 1991: 215). O portugués medieval coñeceu formas como Maudalena e Moudalena, mentres que na toponimia galega predominan as variantes Madanela e Madalena. Todas elas aluden á personaxe bíblica do mesmo nome, que conta cunha capela neste lugar ribadense. 
2.1.8. Pereiriñas, As: Trátase do diminutivo do fitónimo pereira, moi abondoso na nosa toponimia e procedente dun derivado adxectival (*ARBǑRE) PĬRĀRǏA creado a partir de PǏRA, á súa vez plural de PǏRŬM 'pera'. O galego pereira é común ao portugués e correspóndese co catalán perera, mentres que o asturiano e o castelán presentan un derivado peral cunha presenza residual na toponimia galega (Navaza 2006: 410). No caso d'As Pereiriñas non parece probábel pensar nunha variante fonética de pedreira ( $<$ PETRĀRǏA), como si acontece pola contra noutros exemplos.

2.1.9. Ponte, A: Procede do latín PŎNTE 'ponte, pasal', e alude á ponte que existe nas inmediacións e que serve para cruzar o río Grande ou río de Arante.

2.1.10. Portobragán: Ao igual ca noutros topónimos como Portor, Portogaín ou Porcillán, en Portobragán temos a combinación do substantivo porto ( $<$ latín PŎRTŬ) co xenitivo dun nome persoal. Neste caso quizais poidamos falar do antropónimo AFRǏCĀNǓS, con certa presenza na nosa documentación medieval (Africanus 910, 942, 1095; Abrecanus 1010; Abrecano 1097) e que parece estar na orixe doutros nomes de lugar galegos como Abragán, existente na actualidade nos concellos de Ribeira (como topónimo menor), O Corgo e A Estrada. En Pereiro de Aguiar documéntase un topónimo Abregón (de *AFRǏconĪI, xenitivo dun hipotético *AFRǏCONIUUs). Piel (1948: 24) sinala descendentes toponímicos deste mesmo antropónimo en Portugal, como Abregão, Abregã e Abragão. Por tanto, a hipótese dun sintagma * PǑRTŬ AFRICĀNī como orixe da forma Portobragán é conxectural (e implicaría a aférese da vogal inicial do antropónimo), mais conta con apoios de relevancia no sistema toponímico tanto galego como portugués.

2.1.11. Rego de Mel: O substantivo rego ['reyo] (castelán riego) 'pequena canle pola que corre a auga', 'curso de auga pequeno e non permanente' é frecuentísimo no léxico común e toponímico de Galicia e debe ter orixe prerromana, aínda que Sarmiento prefería explicalo a partir do latín RIGO 'regar' $(V G)$, opción tamén defendida por Piel (1945: 317). Pola súa banda, Coromines (DCECH, s.v. RIEGo) decantouse no seu momento polo ibero-vasco *rěcu-. Máis recente é a proposta de Bascuas (2000: 359 e ss.), que retrotrae o termo á primeira colonización indoeuropea da Península Ibérica, atribuíndo a súa orixe á raíz *er- 'moverse, fluír' a través dun tema *rek-, de onde *REKO ( $>$ rego). De todos os xeitos, cómpre lembrar que en galego chegaron a confundirse foneticamente o termo rego que nos ocupa co seu homónimo rego 'suco que deixa o arado', procedente segundo parece do galorromano *rica (< ie. perk-, prk 'suco'), o cal dificulta o estabelecemento dunha liña divisoria clara.

Canto á segunda parte da cadea toponímica, quizais se trate dun topónimo preexistente baseado no cognome latino MERǏ́s, tal e como parece darse noutros exemplos coma 
Mer (Sober), onde se podería postular unha teórica base etimolóxica *(UīLlA) MERĪ̄, a mesma que García Arias (2000: 278) reconstrúe para o asturiano Villamir. Na mesma liña pode interpretarse Soutomel (A Bola), xa atestado na documentación medieval baixo unha forma salto Meri remontábel a un hipotético sintagma latino *SALTŬ MERĪ (Martínez Lema 2010: 247). De todos os xeitos, outra posíbel explicación desta secuencia viría dada polo sintagma *(Uİllāere) Gemellī (Piel 1984: 19), onde GEMELLǓs funcionaría, ao igual que na secuencia anterior, como nome do posuidor. Aínda así, o propio autor recoñece as dificultades de evolución fonética que tal sintagma conleva. Pola súa banda, Nicandro Ares (1996: 74) aduce unha hipotética secuencia *(UĪLLĀRE) MELLǏs, a partir da cal resulta difícil extraer a variante moderna Mel.

2.1.12. Remourelle: Segundo Bascuas (2002: 160 e ss.), Remourelle debe englobarse dentro dun conxunto de topónimos que, como Reguntille, Remourán ou Riomol, entre outros, explícanse pola combinación do substantivo río (< latín RīUŬ) co xenitivo dun antigo nome persoal. No caso de Remourelle ese nome sería o latín MAURĚLLǓS, cuxo xenitivo deu lugar tamén ao topónimo Mourelle, ben representado en Galicia. A prol da interpretación de Remourelle como un antigo * RIUǓ MAURĚLLİ podemos aducir atestacións medievais como Riu Maurelli (s.d.) e Rio Maurilii (s.d.), ambas as dúas extraídas do Tombo de Lourenzá.

2.1.13. Vilamariz: Procede dun antigo (Uīlla) MALARĪCĪ, co xenitivo do antropónimo xermánico MALARĪcǔs no que quizais se recoñeza a raíz *marha 'corcel de batalla', aínda que tamén hai outras opcións como marei 'mar', *marka 'fronteira' ou o gótico amals 'valente’ ( $\mathrm{HgNb} \S 173)$. O segundo constituínte é o gótico reiks 'rico, poderoso'. Á marxe deste topónimo Vilamariz, temos tamén Mariz e Maariz, nos que se perdeu o núcleo nominal UīLlA.

\subsection{CEDOFEITA (Santa María Madalena)}

Esta freguesía aparece mencionada nun documento de 1124 como sancta Maria de Citofacta, nunha permuta entre o monarca Afonso VII e o bispo de Mondoñedo. Atopámola tamén como Citofacta (1202), sancte Marie de Citofacta (1289), Çedofeyta (1286), Cedofeita (1488) e aínda unha variante castelanizada Çedofecha $(1286,1287)$. Unha variante masculina Cedofeito rexistrámola como nome dunha aldea da parroquia de Toxos Outos (Lousame). Segundo as atestacións medievais parece que podemos reconstruír como étimo un sintagma CĬTO FACTA, ou sexa, o adverbio latino сіто 'rapidamente, en breve espazo de tempo' (de onde galego cedo) e o participio perfecto de FACERE. Aludiría por tanto á celeridade con que se realizou unha determinada obra ou construción, probabelmente a igrexa parroquial. 
Dentro do termo de Cedofeita existen os seguintes núcleos de poboación:

2.2.1. Barreiros: O substantivo barreiro significa 'lugar de onde se extrae barro ou arxila', e trátase evidentemente dun derivado de barro (véxase ARANTE, §2.1.1) mediante o sufixo -eiro ( $<$ latín -ĀRǏ $)$.

2.2.2. Burgo, O: Topónimo procedente do xermánico burg- 'cidade pequena', latinizado como BURGǓs en alusión a unha entidade de poboación pequena e dependente doutra situada nas súas proximidades.

2.2.3. Currada, A: O termo currada aparece nos dicionarios galegos, se ben é máis frecuente a variante corrada, xa aboada por Marcial Valladares co significado "Patio principal a la entrada de una casa, especialmente de campo" (DGC), e por tanto sinónimo de curral. Pola súa banda, Acevedo rexistra unha acepción como "Mullido, árgomas o aulagas, paja, etc., que se echa delante de las casas de los labradores para que, pisado, se convierta en estiércol" ( $V B O)$, probabelmente consecuencia dun fenómeno de extensión semántica por metonimia. Xa que logo, parece verosímil explicar currada / corrada en relación con curral, ambos os dous de orixe prelatina (cfr. curro / corro 'curral de pequenas dimensións onde se gardan os apeiros de labranza ou os animais', 'lugar pechado no monte onde se recollen os animais'), ou, segundo outros autores, relacionados co latín CURRǓs ‘carro' mediante unha evolución semántica 'carro' $\rightarrow$ 'lugar para os carros' $\rightarrow$ 'curral' (Álvarez Maurín 1994: 289).

2.2.4. Granda, A: A forma granda (que só se rexistra como topónimo maior na metade oriental da provincia de Lugo) é unha variante do máis común gándara 'terra baixa chea de vexetación brava de pouca altura', 'terreo húmido e pouco produtivo', 'terreo enchoupado ou anegado'. Acevedo (VBO) daba granda como sinónimo de gándara coa acepción "Tierra llana e inculta, del común, llena de maleza”, e sinalou o seu uso na área eonaviega. A orixe de gándara é prelatina, e parece remitir a unha raíz * ganda-, de orixe incerta ( $D C E C H$, s.v. GÁNDARA), á que se lle engadiu o sufixo átono -ăra (cfr. topónimos como Lóuzara, Láncara, Mántaras etc.). A partir de gándara explícase granda como consecuencia da elipse da vogal postónica medial (gándara $>$ gandra) e a metátese da vibrante (gandra $>$ granda).

2.2.5. Igrexa, A: O termo igrexa é variante semiculta do latín vulgar ECCLĒSIIA 'reunión, asemblea dos primeiros cristiáns para celebraren o culto' e, por extensión semántica, 'lugar onde se celebraba o culto'. Tal e como apunta Moralejo Lasso (1977: 296-297), os descendentes patrimoniais do latín ECCLĒSǏA gozaron de grande presenza na nosa toponimia, como p.ex. Eirexa, Eirexe, Eirixe, Grixa e similares. 
2.2.6. O Pedregal: O substantivo pedregal 'lugar cheo de pedras' (cfr. pedral, pedreira, pedranceira....) é un derivado de pedra (< latín PĚTRA) mediante o sufixo -al (< latín -ĀLE) e un elemento afixal -eg- de orixe discutida. Meyer-Lübke (REW6447), reconstrúe un derivado *PETRǏCA. Para Coromines ( $D C E C H$, s.v. PIEDRA), o lóxico é considerar un diminutivo PETRǏCĚLLA que, debido ao seu frecuente uso na fala e na toponimia, faría posible a extensión do tema PETRǏC- a outros derivados.

2.2.7. Piñeiro: Remite ao substantivo homónimo, o cal á súa vez procede dun derivado *IīNARǏL creado a partir do fitónimo latino PīNǓ. A forma galega piñeiro e a portuguesa pinheiro contrapóñense ao resto de dominios romances, que evoluíron as súas respectivas formas a partir do simple PĪNǓ (castelán pino, catalán pi...). De todos os xeitos, o galego contou cunha forma patrimonial piño (medieval pĩo) que chegou a ter implantación no léxico e mais na toponimia mais que cedeu ante o castelanismo pino (Navaza 2006: 414).

2.2.8. Ponte, A: véxase arante, $\$ 2.1 .9$.

2.2.9. Queixoiro: Topónimo que se repite no concello da Fonsagrada e no de Trabada (Marqués Valea 2004: 281), e que forma parte dunha ampla serie toponímica ben representada no noso territorio á que tamén pertencen ítems como Queixeiro, Queixada, Queixa, etc. Meyer-Lübke (REW 1659c), en opinión despois asumida por Piel, remite ao latín vulgar *CAPSĚŬM 'semellante a unha caixa' $(\leftarrow$ CAPSA 'caixa'), que deu lugar ao substantivo queixo 'prominencia da cara correspondente á mandíbula inferior'. Trataríase por tanto dunha aplicación metafórica a zonas cuxo relevo presenta características similares á desa parte da anatomía humana. Menos plausíbel parece a proposta de Coromines ( $D C E C H$, s.v. QUEJAR), que remontaba este termo ao verbo latino-vulgar *QUASSĪĀRE $(\leftarrow$ QUĀSSERE 'sacudir, acanear', 'tremer, enfraquecer'), de onde procedería unha forma verbal antiga requexar / arrequexar 'pór en apuros' que explicaría os topónimos do tipo Requeixo e similares. De todos os xeitos, téñense dado outras explicacións a esta voz, a máis recente de Bascuas (2000: 366), que relaciona Requeixo co hidrónimo *rek-, tema que explica o termo rego e derivados (véxase ARANTE, §2.1.11).

Sexa como for, parece que este tipo de topónimos aluden a lugares profundos ou encaixados no terreo, circunstancia doada de verificar no caso do Queixoiro ribadense, pois trátase dun núcleo de poboación situado no fondo dunha pronunciada vagoada.

2.2.10. Requiande: Segundo Piel e Kremer ( $H g N b$ §219), a orixe do topónimo encóntrase no xenitivo dun nome persoal * RECCINANDŬS reconstruído precisamente a partir deste nome de lugar. De todos os xeitos, a variante feminina Rekenanda 
documéntase nun texto catalán do ano 927 ( $\mathrm{HgNb}$ §219). En ambos os dous casos, o primeiro constituínte sería o gótico $\operatorname{rec}(c)$-, de orixe escura, mentres que o segundo elemento remite ao tamén gótico *nanp- 'ousadía, valor'.

2.2.11. Santo Antonio: Haxiónimo baseado no cognome latino ANTONIǓs, nome dunha gens romana de posíbel orixe etrusca ( $D N G$, s.v. ANTón). Santo Antonio ou San Antonio é o titular de até once freguesías galegas, e a súa pegada toponímica na Península Ibérica pode detectarse en formas como Santo Antão, Santo Antón e San Antonio (Piel 1950: 335). Non puidemos constatar a existencia no lugar ribadense de Santo Antonio dalgunha ermida dedicada ao santo, aínda que si a dunha capela na que se honra a Nosa Señora da Vista ou Virxe do Viso. De feito, o lugar é coñecido tamén polos falantes como $O$ Viso.

2.2.12. Teixido: Derivado abundancial do fitónimo teixo $(<$ TAXŬ), mediante un sufixo que tradicionalmente se interpretou como variante do máis habitual -edo (< lat. -ĒTú), con metafonía, mais que probabelmente sexa un sufixo distinto -īTŬ (Álvarez Blanco 2002).

2.2.13. Torre, A: Procede do latín TŬRRIS 'torre', que deixou descendencia en todos os romances occidentais e conta con proxección na toponimia (DCECH, s.v. TORRE). Cómpre ter en conta certos matices semánticos, como o feito de torre a miúdo designar non só a torre en si mesma, senón o conxunto da fortaleza, ou mesmo a casas señoriais e pazos.

2.2.14. Trapa,A: O substantivo trapa aparece nos dicionarios con diversas acepcións, moitas delas susceptíbeis de uso toponímico. Eladio Rodríguez define a voz como "Puerta o trampa en el piso", mentres que Elixio Rivas (FrampasII, s.v. TRAPA) recolle en Pedrafita o valor "Pequeña madera, accionada por medio de un larguero, para cortar el agua del molino" e en Santa Cruz de Arrabaldo "Trampa". Pola súa banda, Constantino García aboa o significado "Puerta abatible en un agujero que da paso a un lugar bajo, o sobre la cocina" $(G V G)$ e "Trampa", ao tempo que sinala derivados como trapela e trapenla. Segundo Coromines (DCECH, s.v. TRAMPA), estamos perante unha voz onomatopeica trapp / tramp, e indica que se refire tanto a unha "Tabla que se abre en el suelo al pisarla" como ao "Armadijo que se pone para cazar", sentido patente nos termos do catalán, o asturiano ou o portugués. En galego, o uso da variante trampa por trapa (Vázquez Santamarina 1971: 68) non é rara. No asturiano occidental, trapa alude a unha trampa para cazar perdices ou a unha especie de trapela aberta no piso das cortes para botarlle comida ao gando. A alternancia dos temas trap- / tramp- percíbese tamén nos derivados trampallada / trapallada, trampela / trapela (Crespo Pozo 1985: 196) etc. A trapa 'trampa para animais' debeu estenderse ao sitio onde se colocaba. 
Na documentación medieval cítase unha Trapa de Santa María do Mao, no concello do Incio. O portugués ten os nomes xeográficos Trapa e Trapela que Fernandes (2001: 229) explica a partir de $\operatorname{trap}(p) a$ "armadilha para animais selvagens, daí podendo ter tomado um sentido topográfico".

\subsection{COUXELA (Santiago)}

Contamos con varios testemuños deste topónimo na documentación medieval, caracterizados por unha certa inestabilidade gráfica e formal. Na documentación catedralicia de Mondoñedo aparecen variantes como Coiegella 1002, sanctus Iacobus de Coogela 1124 e Coojela 1488. No Tombo de Lourenzá aparece unha forma Coegela (1117). Quizais poida postularse como étimo unha forma *COǓĚLLA, explicábel como diminutivo dunha base *CŏUĨA relacionada á súa vez co adxectivo *CŏUǓs 'cóncavo', 'profundo' (véxase covelas). De feito, o emprazamento de Couxela encóntrase nunha depresión do terreo fronteá ría. Restos dun derivado * CŏǓŭs na nosa toponimia poderían ser formas como Regouxe, se aceptamos con Bascuas (2002: 158) a posibilidade dun étimo * RIUǓ COǓŬ 'río profundo ou encaixado' (cfr. Riocovo e similares), apoiada en principio pola forma recouios baixo a que aparece documentado nun texto de 1204 . En Couxela teriamos unha evolución fonética parcialmente semellante, de admitirmos a transformación da secuencia -UǏ- nunha consoante prepalatal (como FOUĔŬ $>$ foxo, p.ex.), ou ben o mantemento do carácter semivocálico do wau e a consonantización do iode $\left({ }^{*}\right.$ COUǏ̌LLA $>*$ Cougela $>$ Couxela $)$.

Dentro do termo de Couxela existen os seguintes núcleos de poboación:

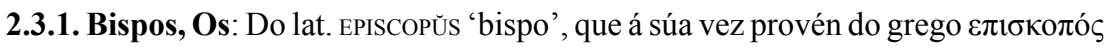
'garda, protector'. As motivacións do topónimo poden ser dúas: por unha banda, pode deberse ao uso deste apelativo como alcume persoal e, nunha segunda fase, como sobrenome familiar, o que explica a flexión en plural; pola outra, talvez se deba á existencia no lugar de terras de xurisdición episcopal. O termo bispo como elemento onomástico persoal é frecuente na documentación altomedieval, tal e como pon de relevo Boullón (1999, s.v. BISPO).

2.3.2. Casais, Os: Trátase da forma pluralizada do substantivo casal 'casa de campo con terras e dependencias', 'pequeno agrupamento de casas no campo'. A orixe do vocábulo atópase no latín CASA (véxase COUXELA, §2.3.3) mediante un derivado adxectival CASĀLIS, cuxo acusativo CASĀLEM explica a forma casal (e a súa variante casar), que cando menos nun comezo parecía referirse a "construcciones precarias, no utilizadas probablemente como vivienda, sino como cobertizo o almacén de los aperos de labranza" (Álvarez Maurín 1994: 305). A presenza de casal / casar 
na nosa toponimia é moi elevada, en ocasións mesmo combinándose con nomes persoais, como vemos en Casalbieito, Casalpeguito e similares.

2.3.3. Casanova, A: O núcleo nominal procede do latín CASA 'cabana de pastor, choupana', quizais un empréstimo ou voz preindoeuropea que desprazou o termo clásico Domus e sobreviviu nos romances (Álvarez Maurín 1994: 304). O adxectivo que o acompaña é feminino de novo (< latín NǒUǔs). O topónimo Casanova, con ou sen artigo determinado, é moi abondoso en todo o territorio galegófono.

2.3.4. Cerdeiriñas, As: Diminutivo do fitónimo cerdeira, que á súa vez remite ao

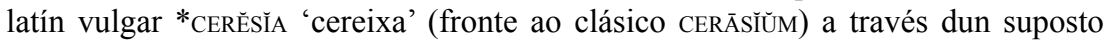
derivado * CERESĀRǏA. A evolución deste último, segundo Coromines ( $D C E C H$, s.v. CEREZA), implicaría unha fase previa cerezeira que pasaría a cerzeira (por síncope da vogal pretónica medial) e este último a cerdeira por disimilación. Existe tamén a variante masculina cerdeiro, mentres que cereixeira, cereixal e similares son formacións máis recentes creadas directamente a partir do romance cereixa.

2.3.5. Cima de Vila: véxase ARANTE, $§ 2.1 .4$.

2.3.6. Fornelo: Diminutivo mediante o sufixo -elo (< lat. -ĚLLŬ) do subst. forno (< lat. FORNŬ). Véxase ARANTE, §2.1.6.

2.3.7. Irexe: Estamos perante unha evolución do latín ECCLESǏA (véxase CEDOFEITA, $\S 2.2 .5)$, na que hai que supoñer varios cambios fonéticos como son a vocalización da consoante oclusiva velar homosilábica (ec- > ei- ou sexa Eirexa), a aférese (talvez motivada polo uso do topónimo en contextos preposicionais, como p.ex. de Eirexa $>*$ de Irexa) e a palatalización da vogal postónica final [a] (> [e]), que conta con moitos paralelos na nosa toponimia, como na propia forma (A) Eirexe, p.ex.

2.3.8. Maizán: Pola súa estrutura, este topónimo quizais poida interpretarse como descendente do xenitivo dun antropónimo, se ben non fomos capaces de precisar exactamente cal, ao carecermos de documentación o suficientemente antiga. Podería pensarse talvez nun nome * MANICİĀNǓs ou similar, pois nun texto do mosteiro de Xunqueira de Ambía con data de 1150 menciónase a un Martinus Manici de Ascalona, onde Manici podería ser o patronímico en xenitivo dun hipotético Manicius.

2.3.9. Moural: A explicación deste topónimo debe encontrarse no substantivo moural, que Aníbal Otero recolleu co valor de "Bestiego. Aplícase a la tierra de aspecto negruzco y a sendas variedades de urce, carpanza y roble" (HERGP). Neste suposto, a orixe desta formación estaría no adxectivo mouro (< latín MAURǓs) ao que se lle engadiu o sufixo -al. 
2.3.10. Rego, O: véxase ARANTE, $§ 2.1 .11$

2.3.11. Sendín: Tanto esta forma como os cognados Sandín e Sindín proceden dun antigo (UİLLA) SENDĪNĪ, xenitivo do antropónimo xermánico SENDĪNǓs, formado á súa vez a partir do gótico sinps 'camiño' e o sufixo xermánico -eins ( $H g N b$ \$241/24).

2.3.12. Venda, $\mathbf{A}$ : Cremos posíbel relacionar este topónimo co derivado regresivo venda 'acción de vender', 'contrato mediante o que se entrega unha cousa por un prezo pactado', procedente de vender (< latín UENDERE). Deste xeito, o topónimo aludiría a unha terra ou porción de terra que foi vendida nalgún momento da historia, acción da que derivou a súa denominación. Lémbranos por tanto outros topónimos galegos como A Manda, A Pensión, A Renda e similares.

2.3.13. Xunqueira, A: Derivado abundancial, mediante o sufixo -eira, do fitónimo xunco (< latín IǓNCŬM), con evolución anómala da vogal tónica etimolóxica quizais debida á nasal homosilábica. O derivado xunqueira funciona como apelativo en galego co significado 'zona húmida onde abundan os xuncos', co cal é sinónimo de xuncal (Ir Indo, s.v. XUNQUEIRA).

\subsection{COVELAS (San Vicente)}

Topónimo ben documentado nos textos medievais, a través de formas como sanctus Uincencius de Couelas (1124), Couelas (1202, 1286), Couellas (1286, 1287), sancti Vincencii de Couelis (1373) ou San Viçenço de Cubelas (1488). Atendendo ás características gráficas destes rexistros (polo demais moi estábeis) e ás propias circunstancias orográficas do lugar (un núcleo habitado encravado no fondo dun pronunciado val) debemos estar ante un diminutivo (mediante o sufixo - ela < latín -ĚLLA) do substantivo cova 'burata, cavidade natural do terreo', tal e como acontece con outros topónimos referidos a entidades coas mesmas características, como Vilacova e similares. A forma cova ascende ao latín hispánico (e quizais prelatino) *CŏUA, que desprazou a forma CAUĚA. A pronuncia espontánea do lugar pecha moito a vogal pretónica, de xeito que é doado escoitar a variante [ku'ß̦عlas].

Dentro do termo de Covelas existen os seguintes núcleos de poboación:

2.4.1. Anzas, As: Documéntase no período medieval como Asanza (1202) e sanctus Tomas de Asanza (1124) na documentación catedralicia de Mondoñedo. O sentido netamente hidronímico do topónimo obsérvase no famoso diploma do Rei Silo (c. 775), no que se alude a propiedades inter ribulum Alesancia et Mera. 
Procede dun derivado ALESANTǏA, creado a partir do radical indoeuropeo *el'vermello, pardo' (IEW 302 e ss.), que acabou tendo usos hidronímicos e xerando topónimos como Esgos (< ALEš̃cōs), Aliso, Alesia, Alistro, Aussonce (< ALISONTĨA) ou, conforme ao que aconteceu con outros radicais hidronímicos similares, tamén un fitónimo como aliso, nome dunha árbore que medra á beira das correntes fluviais (Bascuas 2002: 260 e ss.). No tocante á secuencia sufixal an-t-, é moi habitual na hidronimia de filiación antigo-europea (véxase ARANTE \$2.1), como tamén a secuencia $-\breve{l} a$, sobre todo en combinación coa anterior (cfr. Barbanza $<*_{\text {BARB-ANT- }}$

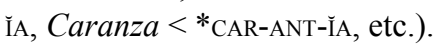

A evolución do primitivo ALESANTǏA dá por vía regular a forma medieval Asanza, sobre a que se produciu unha deglutinación da secuencia inicial [as] (interpretada como artigo determinado, i.e., *As Anza), o cal, á súa vez, determinou a pluralización antietimolóxica do topónimo (*As Anza $\rightarrow$ As Anzas).

2.4.2. Batais, Os: A orixe deste topónimo atópase no apelativo batán 'mecanismo artesán que se arma nun lugar con abundante auga corrente e que, aproveitando a forza que lle proporciona, bate o pano até transformalo nunha especie de feltro'. Máis en concreto, trátase do plural característico da zona (e, en xeral, de todo o galego oriental) para as palabras oxítonas rematadas en $-n$ (batán $\rightarrow$ batais, can $\rightarrow$ cais ou paspán $\rightarrow$ paspais). Canto á etimoloxía, batán é termo de orixe incerta, aínda que pode ascender ao árabe bațtân 'batán', relacionado con bitâna 'pel de carneiro preparada'. Outros autores, en troques, prefiren relacionar batán co verbo bater (< latín BATTǓĚRE) $(D C E C H$, s.v. BATÁN).

2.4.3. Cabana, A: Dun latín tardío CAPANNA, posiblemente de orixe céltica ( $D C E C H$, s.v. CABAÑA). A voz galega cabana conserva, á beira da acepción común 'construción rústica', outras máis específicas e menos frecuentes propias do medio rural, como 'morea de canas de millo de forma cónica' ou 'vaca cos cornos longos e abertos cara ós lados', que en calquera caso non deben estar na base do noso topónimo.

2.4.4. Capela, A: O substantivo capela designa un edificio pequeno destinado ao culto, ou ben a un espazo concreto dentro da igrexa con altar e advocacións particular.

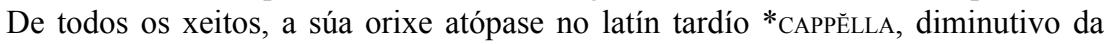
voz de orixe descoñecida CAPPA ( $D C E C H$, s.v. CAPILLA). No lugar en cuestión non perviviron restos de ningunha capela.

2.4.5. Carboeiros, Os: Derivado do substantivo carbón (< latín CARBŌNEM, acusativo de CARBO, -ōNIS) mediante o sufixo -eiro, que neste caso debeu utilizarse para crear un nomen agentis, pois carboeiro aparece nos nosos dicionarios con acepcións como 'persoa que fai ou vende carbón'. De feito, no lugar dos 
Carboeiros existe aínda hoxe a Casa do Carboeiro, que pode facer referencia a esa circunstancia. Xa que logo, Os Carboeiros puido ser un lugar onde noutrora se elaborou carbón ou onde viviron persoas dedicadas a esa actividade que acabaron por darlle nome á zona.

2.4.6. Casa da Hedra, A: Lugar que tomou o seu nome do dunha casa que aínda hoxe existe. O núcleo nominal procede do latín CASA (véxase CouxELA, §2.3.3), mentres que o modificador hedra é o nome dunha planta rubideira (a Hedera helix) coñecida noutras partes do territorio galegófono como hedres, adreira, areira (esta última aboada en Tui polo padre Sarmiento), etc. En última instancia, todas estas variantes representan distintas posibilidades evolutivas do latín HĚDĚRA ( $>$ portugués hera, castelán hiedra / yedra, asturiano yedra / yedre, catalán heura, rosellonés helra... véxase $D C E C H$, s.v. HIEDRA). Outros topónimos relacionados con esta mesma base léxica son Hedrosa, Hedrada, Penadrade, Os Edreiros, Erosa / Herosa, Oroso, etc.

2.4.7. Celeirós: Na base deste topónimo debe estar o substantivo celeiro, que aínda hoxe presenta acepcións como 'construción ou compartimento para gardar os cereais', 'tipo de hórreo', 'alpendre' ou 'sitio da casa que se emprega para gardar as provisións'. O substantivo celeiro procede do latín CELLĀRIŬ, derivado á súa vez de CELLA, vivo hoxe na voz cela 'dormitorio individual nun convento, cárcere ou colexio’. O topónimo Celeirós explicaríase máis en concreto por un diminutivo *CEllaríŏlos $(>*$ Celeirolos $>*$ Celeiroos $>$ Celeirós, con vogal tónica aberta).

2.4.8. Esfolado, O: Cremos que este topónimo se formou a partir do verbo esfolar 'arrincarlle a pel a un animal', procedente do latín vulgar *EXfollāre. Idéntica orixe debeu ter o topónimo As Esfoladas, no concello de Irixoa. A toponimización deste termo puido deberse en ambos os dous casos á súa aplicación metafórica a un terreo pelado e sen vexetación. Tampouco se pode descartar que fose en orixe un sobrenome persoal que acabase por lle dar nome ao lugar, como aconteceu en tantos outros casos.

2.4.9. Marelle: Na nosa opinión, a orixe desta forma debe estar no antropónimo latino AMARELLUS, baseado á súa vez no termo homónimo do latín hispánico que xurdiu como diminutivo do adxectivo AMARus 'amargo' (Boullón 1999, s.v. AMARELO) e que acabou atinxindo o significado cromático que aínda hoxe conserva o seu descendente galego (a)marelo (castelán amarillo). Un antigo sintagma *(UīLLA) AMARĚLLİ explica tanto o topónimo ribadense Marelle (no que se observou a aférese da vogal inicial), así como os topónimos Amarelle existentes no territorio galego. Piel (1948: 27) sinala como descendentes deste mesmo nome persoal o topónimo portugués Amarelhe e o galego Amarelá (dun antigo *(Uīlla) AMARELlāna). 
2.4.10. Mondigo, O: O lugar en cuestión debeu tomar esa denominación a partir da do monte do mesmo nome, a xulgar polo artigo determinado (cfr. lugares como $O$ Ézaro, $O$ Tambre, $O$ Pindo e similares, que toman os seus respectivos nomes do de accidentes xeográficos próximos). O topónimo aparece como Mondiso nun documento de 1002 (debe ser má lectura ou transcrición defectuosa de Mondigo). Unha opción sería explicalo a partir do indoeuropeo men- 'elevarse, dominar' (IEW $726,732)$, raíz sobre a que se xeraron termos orográficos como o latín MONS, MONTIS 'monte' ou o antigo bretón -monid e címrico mynydd 'monte', entre outros. Canto ao sufixo, podería tratarse do sufixo tónico céltico -īko, presente en substantivos como barrica ou artiga (quizais tamén en cantiga, véxase Coromines 1949: 336) e en formacións toponímicas como Amarigo ou Nariga, entre outros (Bascuas 2002: 215).

\subsubsection{Ponte, A: véxase arante, $§ 2.1 .9$.}

2.4.12. Pousadoiro, O: Trátase dun derivado do verbo pousar 'deixar algo nun lugar' (< latín PAUSĀRE), creado mediante a adición do sufixo -(d)oiro, que indica lugar onde se realiza unha acción. Deste xeito, o topónimo Pousadoiro e outros coa mesma orixe (como Pousada ou Pouso, p.ex.) daríalle nome a zonas máis ou menos chás ao final dunha costa, utilizadas para facer un descanso. Un sentido parecido detéctase en compostos como Pousafoles (Padrenda) e Pousacarro (Porto do Son), entre outros. De todos os xeitos, tanto pousadoiro como a variante protética apousadoiro figuran nos nosos dicionarios como voces comúns. Así, Eladio Rodríguez ( $D E G C$, s.v. POUSADOIRo) define o termo como "Descansadero, lugar apropiado para descanso" ou "Arrimadero que hay en algunos caminos aldeanos, para que en él pueda poner la carga el que quiera descansar".

Interpretación lixeiramente distinta é a ofrecida por Ferreira Priegue (1988: 32-33), ao indicar que "al pie de los cruceros, y en previsión de estas estaciones estaba el pousadoiro, especie de banco o mesa donde se depositaba la caja o andas con el cuerpo del difunto mientras se hacía un alto y se le rezaba un responso".

2.4.13. Reme de Arriba: Este topónimo encóntrase ben documentado nos textos medievais, e aparece baixo formas como Raeme (1286, 1287, 1297), Reeme (1297, 1373), as cales evidencian a existencia dunha consoante intervocálica etimolóxica que caeu. Esa circunstancia xerou un grupo vocálico [ae] que evoluíu mediante asimilación ([ee]) e crase $([\varepsilon])$, o cal explica a pronuncia actual do topónimo no que á súa vogal tónica se refire (['reme]). A forma Reme repítese como constituínte dun sintagma máis amplo en Vilarreme, nome dunha localidade do concello do Saviñao que demostra que estamos perante o continuador do xenitivo dun antigo nome persoal. No concello do Saviñao existe un lugar chamado Vilarreme, probábel 
cognado do topónimo ribadense se ben con conservación do núcleo nominal UīLLA. Nicandro Ares (1996: 261) explícao a partir do cognome latino REMUS (LC 202), hipótese que desde logo non pode aplicarse ao Reme ribadense (dadas as devanditas características grafo-fonéticas das súas atestacións medievais).

2.4.14. Sa: Topónimo moi abundante en Galicia e, en xeral, no Noroeste peninsular e que responde á evolución patrimonial do tema xermánico *sala 'pazo, residencia dun señor' (Piel 1989: 123-124). Na toponimia maior coñecemos tamén a variante graficamente máis conservadora Saa, e tamén compostos como Saavedra $(<$ SALA UĚTERA) ou Sasdónigas (< SALAS DOMINǏCAS), entre outros.

2.4.15. Salcedo: Estamos perante a evolución dun derivado abundancial SALǏCĒTǓM creado a partir do acusativo do fitónimo SALIIX 'salgueiro'. O derivado SALǏCĒTǓM deu lugar ao romanés salcet, italiano salceto, francés saussaie e provenzal sauzeda (Aebischer 1950: 70). Na toponimia galega existen tamén as formas femininas Salceda e Saceda, resultado esta última dunha evolución alternativa de SALǏCĒTA (Navaza 2006: 493-496).

2.4.16. San Vicente: Piel (1950: 45-46) indica que San Vicente é un dos mártires máis representativos, motivo polo cal se encontra presente no culto de toda a igrexa latina xa desde época temperá, pois podemos atopar xa documentada unha ecclesia sci Vincentii martyris Valentini na última década do século VI. A forma Vicente explícase a partir do antropónimo latino UǏNCENTIIUs, formado, como tantos outros de inspiración cristiá, a partir do participio de presente dun verbo, neste caso de UINNCERE 'vencer'. Máis en concreto, Vicente remite ao xenitivo UINCENTĪI, mentres que Vicenzo, tamén testemuñado na toponimia, procede do caso recto UINCENTǏU.

2.4.17. Silveira, A: Trátase dun derivado do étimo latino S̆LVA 'bosque', aínda conservado baixo a forma etimolóxica no territorio galego-portugués. Tanto este vocábulo SILVVA como LǓCUS 'bosque sagrado' e sALTUS ‘arboleda' foron reemprazados polo castelanismo bosque de entrada máis tardía.

Este termo sufriu unha extensión no seu significado, pasando de designar nun inicio 'bosque' a nomear á silveira (Rubus fruticosus) 'Arbusto, da familia das rosáceas, que presenta talos longos e espiñentos, follas pequenas e flores de cor branca ou rosada dispostas en corimbos e ten como froito a amora' (Ir Indo, s.v. SILVEIRA).

2.4.18. Somo, O: Debe proceder do latín sŭmmus 'o máis alto', tal e como suxire ademais o feito de se situar nunha elevación de terreo. Marcial Valladares recolleu o termo somo dándoo como arcaísmo e definíndoo como "Cumbre, cima, pináculo, cresta" e "Lo más alto" $(D G C)$. Tamén se rexistra como apelativo o feminino 
soma "Terra que queda a ambos os dous lados dun rego, máis elevada ca a parte central" (Ir Indo, s.v. soma), e para o que Aníbal Otero recolleu outras acepcións como "Altura natural de terreno que, a modo de vallado, divide dos heredades" $(H E R G P)$ ou "Cuando un terreno hace hondonada por un lado y por otro". Termos relacionados con esta base léxica son asomada e asomar, entre outros. Na toponimia maior galega non coñecemos máis exemplos, aínda que si noutros dominios ibéricos, como p.ex. as formas Las Asomadas, La Asomada, La Somada ou La Somadilla, aboadas en Valladolid e que indicarían "eminencia tras la que aparece la visión de un lugar"'(Sanz Alonso 1997: 86).

2.4.19. Vilar, $\mathrm{O}$ : O termo vilar foi moi produtivo na toponimia galega e procede en última instancia dun sintagma *(TĚRRA) UİLLĀRE, cuxo modificador era un adxectivo derivado de Uīlla (véxase Vilela §2.4.20). A secuencia dáballe nome a unha explotación agraria aparecida nos confíns dunha villa e que acababa adquirindo entidade propia (Baliñas 1992: 221), e na actualidade o substantivo ten como acepción máis habitual 'aldea pequena, pequeno lugar'.

2.4.20. Vilela: Trátase do diminutivo latino UILLĚLla procedente do étimo VĪLlA 'casa de campo, heredade' (que á súa vez deriva do radical do vocábulo Uīcŭs). A forma Uīlla sufriu xa no propio latín unha extensión do seu significado pasando a cubrir tamén a acepción de 'poboación de tamaño medio', acepción que se mantén nas linguas romances. No caso do descendente francés ville esta amplificación de significado seguiu evolucionando até cubrir a actual acepción de 'cidade', e será un derivado desta mesma palabra, village, a que recolla o sentido de 'poboación menor'. Debido a isto, para podermos discernir se se trata dun ou outro significado teremos que ter claro cal foi a época en que se fixou o topónimo.

\subsection{DEVESA, A (Santalla)}

O nome da freguesía procede do latín DĒFĒNSAM ( $>$ castelán dehesa), participio de perfecto de DĒFENDŌ 'excluír, protexer' $(D E L L)$, que ademais de 'defender' tamén significaba 'prohibir', acepción esta última que cadra coas restricións as que estaban sometidas antigamente as devesas ou terras adevesadas. Así, o termo devesa designaba arboredos de propiedade comunal cuxo aproveitamento estaba sometido a determinadas restricións. A partir do século XVI as devesas reais, que daquela aínda mantiñan o seu carácter colectivo, pasaron a considerarse propiedade do rei e estaba prohibido extraer madeira ou leña delas, pois esta reservábase para a construción naval. Xa que logo, a (TĚRRAM) DĒFĒNSAM era unha 'terra acoutada', mais o termo devesa desenvolveu tamén outros valores como "Terra cercada destinada a pasteiro ou a bosque" (DLGa), "Terreno más extenso dedicado a cultivo" (DEGC), "Lugar 
poboado de arbustos variados” (C. García 1974: 66), "Terra cerrada con árbores autóctonas, carballos fundamentalmente" (López Castro 1990: 95) etc. Xulia Marqués (2004: 734) indica que en Trabada e en toda a comarca da Mariña "non é un apelativo vivo, aínda que, os topónimos actuais coinciden en designar terreos a monte, polo que, de inicio, o sentido local puido ser 'bosque cerrado"'.

Dentro do termo da Devesa existen os seguintes núcleos de poboación:

2.5.1. Avesada, A: Estamos perante o participio do verbo vesar 'roturar a terra', 'labrar a terra de xeito que os terróns e a codia vaian para o fondo do rego'. Á súa vez, vesar procede do latín UERSĀRE 'roturar co vesadoiro'. Unha vesada é, pois, unha terra gañada ao monte para cultivos, motivo polo cal se rotura. Segundo Eladio Rodríguez, vesada é o "Campo lameiro o prado que se cultiva". Elixio Rivas define o termo como "Terreno llano, algo extenso [...] Tierra labrada" (FrampasII, s.v. VESADA). A forma A Avesada explícase probabelmente pola aglutinación antietimolóxica do artigo determinado feminino (cfr. lagoa / alagoa, bidueira / abidueira e similares).

2.5.2. Barral, O: Para o lexema barro, véxase ARAnTe, $§ 2.2 .1$. Neste caso derivado mediante o sufixo abundancial -al, para indicar os lugares onde a causa da grande humidade o seu terreo e unha especie de lameiro.

2.5.3. Barrio da Campana, O: O galego e castelán barrio (portugués bairro, forma tamén rexistrada nos dicionarios galegos) parece proceder do árabe barr 'periferia dunha cidade', ou mellor dun derivado barrî 'exterior' (Álvarez Maurín 1994: 312). Alude, ao igual ca outros termos como arrabaldo, arrabal e similares, a unha zona habitada situada nas aforas dun núcleo poboacional maior, aínda que tamén pode facer referencia a cada unha das partes nas que se divide ese núcleo poboacional. Canto ao modificador, debe ser unha forma castelanizada de campá ( $<$ latín CAMPĀNA), tal e como parece apuntar o feito de O Barrio da Campana ser o nome das casas adxacentes á igrexa parroquial.

2.5.4. Barrio Novo: véxase Devesa, §2.5.3. Canto ao adxectivo, procede do latín NǑUǓs.

2.5.5. Cepetal: Procede do latín CǏPPǓM 'poste', designando a parte do tronco dunha árbore que queda unido á raíz cando esta se corta. A esta base engádeselle o sufixo - al con valor colectivo ou abundancial. Por outra parte, na pronuncia oral obsérvase unha disimilación da vogal pretónica $(*$ Zopetal), favorecida probabelmente pola presenza dunha consoante bilabial na sílaba seguinte, como en semana $>$ *somana ou levar $>*$ lovar, por exemplo. 
2.5.6. Cinxe: Procede do xenitivo dun nome de posesor xermánico CENDUS, antropónimo xermánico monotemático constituído polo gótico *kind- 'descendencia, estirpe' (HgNb 162 / 8c). De feito, atopamos a forma Cinde como nome dun confirmante nunha doazón ao mosteiro de Bacoi con data de 1010 e contida no Tombo de Lourenzá. O topónimo ribadense ten un cognado Cende no concello pontevedrés de Covelo, o que nos sitúa ante un par similar a outros como Sinde / Sinxe, Quende / Quenxe ou Gosende / Gosenxe. Aínda que Bascuas (2001: 639-640) quixo explicar a forma Cinxe como o resultado dunha asimilación progresiva exercida pola africada dentoalveolar inicial [ts] sobre a oclusiva dental ([d] > [d]]), cremos máis plausíbel pensar en que en todos estes casos tivo lugar unha palatalización da consoante [d] por efecto do -ĩ final do xenitivo (Martínez Lema 2010: 280-281).

2.5.7. Esteiro: Provén do latín AESTUARǏŬM, que podemos definir, ao igual có seu continuador galego esteiro, como "Espazo costeiro produto da invasión cotiá das mareas do medio terrestre na desembocadura dalgúns cauces fluviais e que, as máis das veces, están parcialmente illados do mar por unha barra areosa ou por un estreitamento rochoso" (Ir Indo, s.v. ESTEIRO). É un topónimo frecuente por toda a Galicia costeira.

2.5.8. Lagar, O: Topónimo baseado no apelativo lagar 'depósito onde se expremen certos froitos para extraerlles o zume', 'lugar onde se atopa o lagar', procedente á súa vez dun derivado LACĀLE 'depósito de líquido', que en latín designaba igualmente o lagar de viño e mais o de aceite ( $D C E C H$, s.v. LAGo). Á súa vez, LACĀLE é un derivado do substantivo LĂCUS, para o cal De Miguel (NDLEE, s.v. LĂCUS) ofrece significados como "Lago", "Pila, pilón”, "Cuba de gran capacidad", "Granero para guardar legumbres" ou "La pila en que los cerrajeros y otros artífices templan los metales".

2.5.9. Liñeiro: O latín LĪNŬM deu lugar ao galego liño (portugués linho, castelán lino), nome da planta que ten como nome científico Linus usitatissimum. Xa en latín, a TĚRRA LīNĀRǏA aludía ás terras nas que se cultivaba o liño manso. O derivado liñeiro, que pode considerarse xa como de formación romance, faría mención a esta circunstancia, pois os nosos dicionarios adoitan recoller o vocábulo como sinónimo de liñar, aínda que Eladio Rodríguez ( $D E G C$, s.v. LIÑEIRo) aboa tamén o significado "Persona que trata en tejidos de lino".

Unha outra opción etimolóxica (ao noso xuízo menos probábel) sería relacionar liñeiro co substantivo leña, que remonta en última instancia ao latín LIGNUM 'madeira'. De feito, Elixio Rivas recolleu a forma liñeiro en Friol como "Sitio de la leña" (FrampasII). Trataríase en orixe dun derivado leñeiro, cuxo paso a liñeiro podería deberse á acción do ditongo decrecente [ej] e / ou á da consoante nasal palatal. 
2.5.10. Meirengos: No Tombo de Lourenzá aparece notado de diferentes maneiras: Meyringos, Meyrengos, Mairengos, Meirengos (s. XIII), rexistros que poderían facer pensar nunha posíbel relación co termo meiriño ( $<$ latín MAIORĪNǓM). Mais, por outra parte, o vocábulo contén o sufixo -engo, bastante usual na creación de xentilicios, é dicir, adxectivos derivados de nomes de lugar e/ou señoríos. Deste xeito, o topónimo podería estar dando nome a un lugar que recibiu xente desprazada doutra localización xeográfica, concretamente neste caso de Meira, tal e como acontece con outros topónimos galegos que fan referencia á mesma circunstancia histórica, como Meirás (medieval Merianes Tombo de Sobrado 1122). Mais ao non atoparse até o momento documentación máis antiga, o que vimos de dicir non pasa de ser unha mera hipótese.

2.5.11. Noceda: Procede dun derivado NǓCĒTA creado mediante a adición do sufixo de valor abundancial -ĒTA á forma NǓCEM, acusativo do latín NŬX 'noz'. Relativamente preto deste lugar, no concello de Trabada, rexístrase unha forma $A$ Nocenda, cunha consoante nasal antietimolóxica. Este mesmo procedemento podemos rexistralo en formas como, por exemplo, o adverbio ninguén < NEC QUEM, etc.

2.5.12. Olleiros, Os: Derivado do substantivo ollo ( $<$ latín ǑcŭLŬM), que neste contexto desenvolveu a acepción de 'nacente de auga'. O topónimo Os Olleiros ten un significado máis específico de 'punto en que asoma a auga'. Nos lugares costeiros do concello parece contar cunha considerábel produtividade, mais facendo alusión á auga do mar que entra en terra: Ollo Redondo, Ollo de Porto, Ollo de Estornín, Ollo Cheirón, etc.

2.5.13. Pedreira, A: Derivado do substantivo pedra (< latín PĚTRAM), lexema de grande produtividade na toponimia galega. Máis en concreto, o substantivo pedreira presenta en galego valores como "Pedrera, cantera, sitio o lugar de donde se sacan las piedras" ou "Montón de piedra sacada ya de la misma cantera" (DEGC, s.v. PEDREIRA).

2.5.14. Preixoana, A: Interpretamos este topónimo como evolución dun primitivo sintagma *A Pereira Xoana, onde por posición proclítica, se perde a última sílaba (A Perei’Xoana) para finalmente sincoparse a vogal pretónica (A Preixoana). Parece razoábel pensar na intervención do xinecónimo Xoana ao igual que noutros nomes de lugar afíns e estruturalmente máis transparentes, como Fontexoana, no concello de Cervantes.

2.5.15. Rato, O: O topónimo $O$ Rato pode ter cando menos tres vías de explicación, xa que polo momento non fomos capaces de localizar documentación medieval que permita comprobar a súa orixe. Por un lado podería tratarse dun alcume (medieval 
ou posterior) do dono desas terras, mais tampouco debería descartarse que se tratase dun lugar onde se pagaba unha renda rata no sentido dunha renda ratificada ou confirmada. A terceira hipótese é que proveña de RAPTǓM, participio do verbo latino RAPĪo, que faría alusión á forza do río, coma no caso do seu homónimo, o río lugués Rato. Como explicación ao anterior debemos dicir que até o momento non se atopou documentación onde conste nin o alcume nin a referencia a unha renda especial, e atendendo ás características do terreo trátase dun lugar bastante chan onde hai un regato que conta cun caudal pequeno de auga. Por outro lado, unha cuestión que nos parece significativa é que o nome designa o lugar e non propiamente o río, xa que para se referir ao curso de auga utilízanse denominacións como Río de Sá ou Río do Lagar; é por este motivo que a denominación de Río do Rato parece tamén puramente locativa (ao igual cás outras dúas), tomando os nomes dos lugares polos que transcorre e non como nome propio do río, mais esta situación puido non ser a mesma antigamente e agora ficar así simplemente pola perda da consciencia do referente.

2.5.16. Rochela, A: Trátase dun diminutivo mediante o sufixo -elo (< latín -ĚLLŬs) do substantivo rocha 'pedra, penedo' (castelán roca), moi presente na nosa toponimia ben a través da forma simple ben mediante derivados como Rocheira, Rochiña, a propia Rochela e similares. Malia esta rendibilidade, a orixe do apelativo rocha non está demasiado clara, aínda que podería tratarse dun galicismo (Marqués Valea 2004: 229).

2.5.17. Viladroiro, O: Aparece como Braladuiro nun documento catedralicio de Mondoñedo con data de 1202. No Tombo de Lourenzá atopámolo nas secuencias antroponímicas Petrus Gundisaluiz de Bruladuru (c. 1150-1266) e Petro Gunçalviz de Bruladoyro (1258), alusivas ambas as dúas ao mesmo personaxe. Son, até onde nós sabemos, os únicos testemuños deste topónimo nos textos medievais. Deles podemos tirar algunhas conclusións: en primeiro lugar, a xulgar polo sufixo -(d) oiro, que se trata de derivados deverbais nos que o devandito afixo achega a idea de 'lugar onde se realiza ou ten lugar unha acción'; en segundo lugar, que a base léxica acabou por asociarse co substantivo vila, seguramente pola concorrencia nesa contorna xeográfica de topónimos como Vilagoíz, Vilandriz, Vilaselán ou Vilaframil, entre outros. Non sabemos con certeza cal pode ser o lexema verbal sobre o que se formou esta denominación toponímica, e só podemos facer conxecturas a partir dos poucos datos de que dispomos. Unha posibilidade sería pensar no verbo brullar, que Elixio Rivas (FrampasII, s.v. BRULLAR) define como "Silbar, sonar el viento". Trataríase por tanto dun lugar onde zoa especialmente o vento, circunstancia coherente coas propias circunstancias orográficas do lugar (situado nunha elevación do terreo non demasiado afastada do mar) e tamén coa existencia no territorio 
galego doutros nomes de lugar referidos a esa mesma característica ( $O$ Mesón do Vento, Ventosa... $)^{3}$.

2.5.18. Vilagoíz: É posíbel remontar este topónimo a unha secuencia do tipo *UīLla GAUDĪTĪI, sendo o seu propietario un individuo de nome GAUDITIǓs ou GAUDIČǏs. Nos Tombos da Catedral de Mondoñedo aparece rexistrado baixo as formas uilla Uolisi e Uillaurt (má lectura por Uillauit), ambas as dúas nun documento con data de 1002.

O nome persoal GAUDIǓs ( $N L$ 46) xerou segundo Piel (1948: 76) un elemento patronímico xa romance Góis, que podería ser a base do segundo constituínte deste topónimo. Segundo este autor, a forma en cuestión "explicar-se-ia de um modo fonològicamente satifatório pelo patronímico Gaudizi, apontando acima, que, como todos os apelidos deste tipo, recebe o acento do tema”.

2.5.19. Vilandriz: Provén moi posibelmente dunha forma *Uīlla ANDERĪcī, que rexistramos nos Tombos da Catedral de Mondoñedo baixo variantes como uilla Aldrisi e Villam Aldrit, en senllos documentos do 1002. O antropónimo ANDERĪCǓs (Boullón 1999: 131) alude a unha procedencia xermánica cuxa forma está constituída por dúas bases difenciadas: por unha parte, o tema and- de xénese escura, quizais gótica, e pola outra a terminación xermánica -reiks. A forma Andericus aparece varias veces como nome de posuidor na documentación medieval do Tombo de Sobrado.

2.5.20. Volta, A: Este topónimo debe explicarse a partir do participio do verbo latino UǑLUĚRE, de onde xurdiu o verbo volver, común a galego, portugués e castelán. $\mathrm{O}$ substantivo volta, entre outros valores, utilízase en galego con significados como ‘curva, ángulo dun camiño ou dun río' ou 'cambio de dirección ou desvío dun río ou dun camiño', ambos os dous susceptíbeis de uso toponímico. No caso que nos ocupa trátase da volta que fai o camiño que pasa polo núcleo habitado en cuestión.

\subsection{OVE (San Xoán)}

Contamos con abondosos testemuños deste topónimo na nosa documentación medieval, como Eouo (1002), sancto Iohanne de Eoue (1002), sanctus Iohannes Euue (1124), Oue (1343) e San Juan d-Obe (1488), que nos permiten ir observando a evolución desta forma e determinar a súa procedencia etimolóxica. Trátase sen dúbida dun hidrónimo que tamén intervén como constituínte do topónimo Ribadeo,

3 De feito, pode aducirse como dato de interese que no veciño lugar de Meirengos existe unha casa aínda hoxe coñecida como Casa de Ventoso. 
se ben experimentou evolucións diverxentes nunha e outra forma. Coincidimos basicamente con Bascuas (2002: 199 e ss.), quen, a partir das atestacións que vimos de aducir e dalgunhas outras, reconstrúe un composto *Ǒ̌w-upe, formado a partir dun tema *ŏ̌wo- (da raíz indoeuropea *ei- 'ir', cfr. antigo indio éva- 'corrente' e similares) que tamén podemos illar noutros potamónimos como Evas, Eume, Ebo, etc. $\mathrm{O}$ segundo elemento dese composto é a forma atemática *-upe, tamén con valor hidronímico en tanto que se relaciona probabelmente co radical *up-, variante alternante de *ăp- / *āp- 'auga, río' (IEW 52, 1149 e ss.).

Dentro do termo de Ove existen os seguintes núcleos de poboación:

2.6.1. Aceñas, As: O termo aceña remonta ao árabe as-sâniya 'nora', 'muíño fariñeiro' ( $D C E C H$, s.v. ACEÑA). Este vocábulo coñeceu unha dupla evolución en galego no que respecta ao tratamento da consoante nasal, que nun caso se fundiu co iode para dar lugar a unha nasal palatal (aceña), mentres que noutro sufriu lenición e síncope (acea). De feito na propia zona conviven oralmente as dúas denominacións para o lugar. As aceas son variantes dos muíños de auga e parecen ser de introdución relativamente recente (Marqués Valea 2004: 802), precisamente no lugar das Aceñas aínda existen restos de antigas construcións deste tipo, das que tomou o nome.

2.6.2. Acevedo: Derivado abundancial (co sufixo -edo) de acevo ( $<$ lat. AQUIFŎLIŬ). Aínda que o noso acevo deriva dunha forma un tanto afastada do latín clásico como é a forma *ACǏFŎLUM, onde a primeira parte do vocábulo, ACI, achega o significado de 'agudo' e a segunda FOLIIUM o de 'folla', facendo alusión, por tanto, ás características da forma das súas follas.

2.6.3. Capela, A: véxase covelas, $\$ 2.4 .4$.

2.6.4. Casas Novas, As: véxase couXela, §2.3.3.

2.6.5. Chao de Ove, O: O núcleo nominal ao redor do que se vertebra este sintagma toponímico procede do adxectivo latino PLĀNǓS 'chan', posteriormente substantivado. A solución chao é a propia do galego central e oriental, fronte á variante chan das falas occidentais e canonizada no galego estándar.

2.6.6. Covo, O: Procede do adxectivo hispano-latino *CŏUUS, -A, -ŬM, e aplicaríase a un terreo de orografía cóncava. Estreitamente relacionado co anterior CovELAS $\$ 2.4$.

2.6.7. Eirexa, A: véxase couxela, §2.3.7. A Eirexa é unha forma máis conservadora que mantivo o ditongo inicial e o timbre etimolóxico da vogal postónica final. 
2.6.8. Escaleira, A: Procede do étimo latino SCALĀRǏAM, que á súa vez remite a SCĀLA. O termo escaleira ten como significado máis habitual "Plano inclinado que serve para pasar dun nivel a outro mediante a descomposición da distancia vertical en chanzos adaptados á medida dun paso" (Ir Indo, s.v. ESCALEIRA). Neste caso en concreto, parece que a denominación toponímica podería ter xurdido por extensión semántica partindo da similitude formal entre o obxecto e a superficie á que fai alusión. Aínda así, podemos encontrar outro tipo de definicións plausíbeis que dean explicación ao uso desta palabra común para denominar un terreo. Así, Dobarro (1974: 141) aboa para a forma escada 'escaleira nun muro que permite o acceso a unha leira' ou Vázquez Fernández (1971: 100) no mesmo sentido 'escalón ou grada de ascenso que fai accesible a entrada dun carro a un terreo'.

2.6.9. Estación, A: Topónimo baseado no substantivo estación 'lugar onde un vehículo recolle e deixa mercadorías e viaxeiros', procedente do latín STATǏ̄NE, á súa vez derivado do verbo STĀRE. Efectivamente, neste lugar atópase a estación de ferrocarril da liña Ferrol-Xixón.

2.6.10. Faxarda, A: Resulta factíbel explicar este topónimo a partir dun antropónimo non documentado *FAGİADǓS ou similar, xerador en última instancia do apelido (é de supoñer que noutrora nome persoal) Faxardo.

A constitución dese antropónimo pode explicarse a partir da onomástica persoal xermánica, pois o tema inicial sería fak- / fag- (identificábel co gótico * fahs 'alegre', fahêps 'alegría' ou faginôn 'alegrarse', véxase Boullón (1999), s.v. FAGILDUs), mentres que o segundo elemento é o fráncico hardus 'duro, sólido'. A partir dese nome persoal, a forma toponímica $A$ Faxarda poderíase interpretar como forma feminina do apelido Faxardo antes mencionado: por exemplo, como alusión a unha muller provista dese apelido que viviu noutrora no lugar en cuestión.

2.6.11. Frieira a Nova / Frieira a Vella: Acevedo recolle frieira nas áreas contigüas ao río Eo co valor de "Sabañón" $(V B O)$, mais parece moi improbábel que ese significado puidese motivar unha denominación toponímica. Quizais haxa que fixarse en acepcións como: "Arroyuelo" (Valladares), "Arroyuelo, torrente" (Filgueira), "Sitio donde se siente mucho el frío" (Eladio), "Caída de agua" (Elixio Rivas), "Paso estrecho de agua en el río" (Constantino García) e similares. O étimo sería un derivado creado mediante a adición do sufixo -ĀRǏA ao adxectivo FRĪGIDǓs $(>$ frío).

2.6.12. Garitos, Os: Topónimo baseado no substantivo garito, que entre outros significados presenta o de 'cuarto pequeno e mal arrombado'. Estreitamente relacionados están termos como garita 'caseta que serve de abrigo e defensa a un 
sentinela', procedente do francés garite 'refuxio' e do que probabelmente proceda o vocábulo que nos ocupa. En última instancia, a orixe desta serie de formas é o xermánico warjan, xerador de apelativos semanticamente vinculados aos anteriores como gorecer e similares (Ferreiro 1999: 106).

2.6.13. Graña, A: O vocábulo graña, conservado só na toponimia, parece proceder do latín GRĀNĚAM, adxectivo derivado do substantivo GRANŬM 'gran'. Segundo Elixio Rivas (1982: 281), a *UĪLla GRANĚA era orixinariamente a parte da villa romana que albergaba os celeiros onde se almacenaba o gran, para máis tarde denominar o conxunto do lugar. Tradicionalmente considerábase que o termo granxa, que acabou prevalecendo como apelativo e desprazando a voz tradicional graña, era adaptación do francés grange, á súa vez procedente dun derivado latino-vulgar *GRANǏCA. Este galicismo, como tantos outros, sería introducido polos monxes cistercienses. De todos os xeitos, non debería descartarse que graña e granxa sexan en realidade evolucións distintas do mesmo étimo GRANĚA: no primeiro caso, o iode embebeuse na nasal, dando como resultado a nasal palatal; no segundo, en troques, o iode consonantizou, xerando a actual consoante prepalatal.

2.6.14. Grañol: Quizais poida explicarse este topónimo a partir dun antigo *(Uīlla) GRANǏ̌LII no que se observa o xenitivo dun nome persoal *GRANǏLLǓs. Aínda que esta forma non se documenta como tal, si consta a correspondente variante de feminino, ou sexa GRANNǏ̌LA (LC 1982: 167). Segundo parece, trátase dunha serie antroponímica prerromana á que pertencen outros termos como GRANNUS, GRANNOS 'radiado', utilizado como epíteto de Apolo en territorios de cultura e lingua céltica (Boullón 1999, s.v. GRANILO). Desde o punto de vista da evolución fonética, o xenitivo GRAŇǒlī pasa a Grañol en virtude da apócope do -ĩ final, como en Ferrol (vs. Ferroi), Piñor / Piñol (vs. Piñoi) e outros antrotopónimos con similar estrutura fonética.

2.6.15. Guildeiros, Os: Seguramente haxa que pensar nun derivado do fitónimo guinda, de orixe incerta, ou máis en concreto da variante guilda que Elixio Rivas (FrampasII) xa rexistra en Betán (Ourense) como nome da árbore que produce os ditos froitos. Segundo Coromines ( $D C E C H$, s.v. GUINDA), podería proceder dunha forma xermánica romanizada *WĪKSǏNA da que resultarían tamén o antigo catalán guíndola, o antigo occitano guilha, guina ou o francés guigne. De paso, o filólogo catalán rexeitaba a hipótese formulada por Meyer-Lübke, quen vía a base última do vocábulo no grego BYSSǏNus 'vermello' (Marqués Valea 2004: 387).

2.6.16. Malatos, Os: Procede do termo italiano malato (< MALE HABITǓs) 'enfermo', apelativo empregado para referirse aos hospitais que na Idade Media se crearon para recoller os enfermos de lepra. A malataría de Ribadeo foi fundada no s. XIV, e seguramente este topónimo ten que ver coa súa existencia. 
2.6.17. Palmeira, A: Pode remitir ao fitónimo homónimo, que designa polo xeral a Palma Phaenix dactilifera e que procede do latín PAlma. De todos os xeitos, tampouco poden descartarse outras opcións, como o substantivo palmeiro, derivado á súa vez do fitónimo palma e que, tal e como indica Eladio Rodríguez (DEGC, s.v. PALMeIro), aludía ao "Peregrino de Tierra Santa, que traía palma, como los de Santiago llevaban conchas o veneras en señal de su romería". Neste caso, a toponimización podería vir dada mediante o seu uso como nome de casa.

2.6.18. Pastoriza: O termo pastoriza (notabelmente representado na nosa toponimia) aparece recollido en varios dos nosos dicionarios. Eladio Rodríguez (DEGC, s.v. PASTORIZA) define o vocábulo como "Albergue de pastores" e "Pastizal, terreno de pasto abundante”. Elixio Rivas (Frampas II, s.v. PASTORIZA) recólleo no Morrazo como "Zona de pastos, vega de pastos", mais indica o seu carácter arcaico. Desde o punto de vista da etimoloxía, pastoriza procede do latín PASTORĪCIǓs, derivados á súa vez do participio do verbo PASCĚRE 'pacer' (Rivas 1982: 294-295).

2.6.19. Pega, A: Posibelmente teñamos como orixe deste topónimo o ornitónimo pega, do latín vulgar *PĒCA (pola forma clásica PǏCA 'pega', 'especie de gralla'). De ser isto certo, quizais a súa toponimización, como noutros casos xa comentados, viñese dada a través dun previo uso antroponímico, i.e., como sobrenome persoal. De feito, aínda hoxe existe na freguesía de Ove a familia dos Pegos. O topónimo repítese noutros puntos de Galicia, concretamente nos concellos de Abegondo, Cambre, Ferrol e Sada, mentres que no de Neda rexístrase o sintagma A Corredoira da Pega.

2.6.20. Reme: véxase COVELAs, $\S 2.4 .13$.

2.6.21. Río de Ove, O: Procede do termo latino RīuǓs 'rego, canle', reducido no latín vulgar a * RIUS como xa se pon de manifesto no Appendix Probii. Ademais, neste termo confluíron tamén os valores procedentes de FLUMEN. Como se pode comprobar, o vocábulo río aparece acompañado dun complemento locativo (neste caso o topónimo Ove, véxase ove §2.6), marcando deste xeito o tramo fluvial co nome do espazo polo que transcorre.

2.6.22. Río de Ramos, O: Para o núcleo río, véxase ove, §2.6.21. O substantivo que actúa como modificador é ramo, procedente do latín RĀMǓs 'póla, rama'. Coromines ( $D C E C H$, s.v. RAMO) sinala que ramo reservouse para designar os gallos pequenos dunha rama, así como para usos figurados. Segundo Marqués Valea (2004: 513), "seguramente os nosos topónimos Ramo e derivados retratan a vexetación vizosa destes lugares ou indican sitios onde se derramaba". A presenza de Ramos como modificador nesta secuencia toponímica quizais se explique pola identificación da 
corrente fluvial en relación a un lugar noutrora coñecido como Ramos. Tampouco sería descartábel a toponimización deste vocábulo a través do seu uso como apelido persoal, moi estendido por toda Galicia.

2.6.23. Río Pequeno, O: Para o núcleo río, véxase ove, §2.6.21. O modificador é o adxectivo pequeno, común ao portugués (vs. castelán pequeño), e segundo parece resultado do cruzamento do latín vulgar *ǏTIINNǓs co radical *pikk-, presente no italiano piccolo e piccino (DLP, s.v. PEQUENO).

2.6.24. San Lázaro: Trátase dun nome bíblico, o arameo La'azar 'Deus axudou', que pasou ao latín como LAZARus (Boullón 1999, s.v. LAZARus). Asóciase este santo aos doentes de lepra, e no lugar en cuestión existe unha capela con esta advocación. A presenza deste antropónimo na nosa toponimia non só veu por vía haxionímica, pois a forma Lázare (Guntín) parece suxerir un antigo *(UīLlA) LAZARĪ ou similar.

2.6.25. Santa Cruz: Trátase dun haxiotopónimo relativamente frecuente e antigo, obviamente referido á cruz da paixón de Cristo. Piel (1950: 84-85) indica que "a festa da Invenção da Vera Cruz, de origem palestiniense, e instituída para conmemorar a consagração das basílicas erigidas por Constantino nos lugares do S. Sepulcro e do Calvário, é inscrita, nos calendários primitivos peninsulares, a 3 de Maio”.

2.6.26. Seixadelo: Segundo parece, estamos perante un descendente toponímico do substantivo seixo 'coio pequeno e listo' (< latín SAXǓ), ao que se lle engadiu dupla sufixación: -edo $(<-\bar{E} T \breve{\text { ) }}$ e do diminutivo -elo $(<-$ ĚLLŬ$)$. Trataríase por tanto dun lugar de pequena extensión e singularizado pola presenza de seixos. A forma esperábel a partir dese suposto derivado *SAXETĚLLǓ sería *Seixedelo, mais debeu producirse unha disimilación que explica a solución actual.

2.6.27. Travesas de Ove, As: Procede do termo latino TRĀNSVĚRSAM 'transversal'. A motivación pode vir dada polas barreiras do paso a nivel do antigo ferrocarril do mineral que alí se encontran. Aínda así, na documentación antiga podemos encontrar a secuencia pezas travesas en alusión a terreos 'dispostos de través'. Marqués Valea (2004: 717) cita tal uso presente nun documento privado da parroquia de Sante. Para a forma $O v e$, véxase ove $\S 2.6$.

2.6.28. Valín, O: Diminutivo creado sobre o substantivo val (< latín UALLE) mediante o sufixo diminutivo -ín, evolución do latín -ĪNŬ característica da zona que nos ocupa e, en xeral, do conxunto do galego oriental. O xénero masculino de val (fronte ao xénero feminino que tiña o seu étimo latino) denota o carácter relativamente recente do topónimo. 
2.6.29. Veigadaira, A: Topónimo analizábel como unha antiga secuencia * A Veiga da Aira, resultado da combinación do substantivo veiga e do substantivo aira.

O vocábulo veiga é moi frecuente no léxico toponímico de Galicia. Recólleo xa Reguera co significado "Vega. En tierra de Lugo unos prados húmedos que solo dan pasto para el ganado y no sirven para yerba verde ni para heno. Por lo común estan a las márgenes de los ríos, y también los hay en otros puntos pero siempre húmedos. Por su agua encharcada no sirven para otro uso", e faino sinónimo de braña. De todos os xeitos, as acepcións do termo varían sensibelmente dunhas áreas de Galicia ás outras. Na zona que nos ocupa, o substantivo veiga designa un prado situado nas marxes dun río e caracterizado pola súa humidade. Desde o punto de vista da etimoloxía, o vocábulo ascende ao substrato prelatino, aínda que se deron distintas interpretacións. Menéndez Pidal (1968: 15) reconstruíu un derivado *vaika formado pola base bai 'río' e o sufixo $k a$ 'rexión do río', e adscribe o termo ao fondo ibero. Hubschmid (1960: 458) optara por un sintagma *(TĚRRA) (I)BAIKA co significado 'terreo nas beiras dunha corrente de auga', relacionándoo co éuscaro ibai 'río'. Máis recentemente, Villar Liébana (2000: 245) defendeu a orixe indoeuropea do termo. O certo é que o vocábulo non existe só en galego e portugués, senón que tamén se rexistra en castelán e sardo, e aínda esporadicamente no aragonés.

Canto ao modificador aira, procede do latín ARĚA 'solar sen edificar', 'eira dunha granxa'. Deste termo deriva, por evolución fonética regular, a voz eira, propia da maior parte de falares galegos; pola contra, a variante aira, en que se conservou o ditongo secundario [aj] resultante da metátese do iode, restrínxese ás variedades galegas centro-orientais. De todos os xeitos, o galego eira / aira ten o seu correlato no asturiano e castelán era. O significado básico (o que se rexistra ademais na zona que nos ocupa) pode expresarse como 'espazo de terra descuberto próximo á casa e no que se mallan os cereais, póñense a secar os legumes, etc.'; malia iso, cómpre non esquecer outras acepcións verificadas noutras zonas do país, como "Sembrado de hortalizas, que más conmunmente se llama horta" (DEGC, s.v. EIRA), entre outros.

2.6.30. Vilar: véxase Covelas, $\$ 2.4 .19$.

2.6.31. Vilavella, A: Sintagma nucleado polo substantivo vila (véxase ARANTE, $\S 2.2 .4$ ) e no que actúa como modificador o adxectivo vello, procedente da forma latino-vulgar *UĔTǓLǓS, que se creou á súa vez sobre o termo clásico UETŬs, -ERIS. No lugar da Vilavella estivo o emprazamento orixinal da freguesía de Ribadeo, e o da primitiva igrexa de Santiago de Vigo. 
2.6.32. Xardín, O: Procede do termo francés jardin, forma diminutiva do francés antigo jart 'horto', en fráncico * ${ }_{\mathrm{GARD}}$ 'cercado, sebe'. Este vocábulo tivo unha posterior extensión semántica que o levou a significar en galego "Espazo de terreo delimitado, ordenado e cultivado con plantas ornamentais" (Ir Indo, s.v. XARDÍN).

\section{Cabo}

O estudo das denominacións dos lugares, neste caso da denominada macrotoponimia ou toponimia maior, presenta diversas utilidades e aplicacións prácticas, entre elas a de servir como complemento auxiliar doutras disciplinas lingüísticas como a gramática histórica. En concreto, a análise das diversas categorías toponímicas (antropotopónimos, hidrotopónimos, fitotopónimos, orotopónimos, etc.) relaciónase, por unha banda, cos hábitos da construción denominativa das distintas realidades circundantes ao ser humano e, pola outra, entronca directamente co contexto socio-cultural que os rodea (especialmente relevante nos hábitos de construción de sintagmas antroponímicos fosilizados en topónimos de base persoal). Este tipo de interaccións resúltannos dunha grande utilidade para establecer a datación, cando menos aproximada, de moitas desas estruturas toponímicas. Por exemplo, o carácter indiscutibelmente achegado no tempo de O Barrio da Campana (onde o segundo elemento xa concorreu na estrutura coa forma castelá debido á súa recente incorporación ao repertorio) fronte ao máis antigo de formas como Vilandriz ou Vilagoíz (onde a filiación xermánica do segundo elemento adoita remitir a un período cronolóxico anterior incluso ao da toponimia de base latina). Por outra parte, son frecuentes os casos de hibridismo ou etimoloxía híbrida neste tipo de repertorios, é dicir, acostuma acontecer que un único ítem toponímico se compón de elementos de distinta orixe etimolóxica, ben resultante da unión de bases léxicas de filiación lingüística diferente, ben da unión dunha base léxica cun afixo ou afixos de procedencia diversas (especialmente no ámbito da hidronimia).

Por último, e desde o punto de vista da normalización e estandarización lingüística do idioma galego, este tipo de traballos ofrecen unha visión máis completa e exhaustiva que axuda á comprensión cabal e á reconstrución da forma xenuína de numerosos topónimos para os cales os nomenclátores ofrecen aínda hoxe propostas dubidosas ou incluso incorrectas. Mais, aínda así, é evidente que fican no ar moitas cuestións pendentes que esixen afondar nas liñas de traballo abertas e enriquecelas con novos estudos e perspectivas. 


\section{4. Índice de formas}

\begin{tabular}{|c|c|}
\hline Aceñas, As (§2.6.1) & Cinxe $(\$ 2.5 .6)$ \\
\hline Acevedo $(\S 2.6 .2)$ & Couxela $(\S 2.3)$ \\
\hline Anzas, As $(\S 2.4 .1)$ & Covelas $(\S 2.4)$ \\
\hline Arante $(\$ 2.1)$ & Covo, O $(\$ 2.6 .6)$ \\
\hline Avesada, A (§2.5.1) & Currada, A (§2.2.3) \\
\hline Barral, O (\$2.5.2) & Devesa, A $(\S 2.5)$ \\
\hline Barredal, O (§2.1.1) & Eirexa, A $(\S 2.6 .7)$ \\
\hline Barreiros $(\S 2.2 .1)$ & Escaleira, A (\$2.6.8) \\
\hline Barrio da Campana, O $(\S 2.5 .3)$ & Esfolado, O (§2.4.8) \\
\hline Barrio Novo, O (§2.5.4) & Estación, A (\$2.6.9) \\
\hline Batais, Os $(\$ 2.4 .2)$ & Esteiro $(\$ 2.5 .7)$ \\
\hline Bestilleiros, Os (\$2.1.2) & Faxarda, A (§2.6.10) \\
\hline Bispos, Os $(\S 2.3 .1)$ & Fondo de Vila $(\S 2.1 .5)$ \\
\hline Burgo, O (§2.2.2) & Fornelo $(\S 2.3 .6)$ \\
\hline Cabana, A $(\S 2.4 .3)$ & Fornos, Os $(\S 2.1 .6)$ \\
\hline Capela, A (§2.4.4), (§2.6.3) & Frieira a Nova $(\S 2.6 .11)$ \\
\hline Carboeiros, Os $(\S 2.4 .5)$ & Frieira a Vella $(\$ 2.6 .11)$ \\
\hline Casa da Hedra, A (\$2.4.6) & Garitos, Os $(\$ 2.6 .12)$ \\
\hline Casais, Os $(§ 2.3 .2)$ & Graña, A (§2.6.13) \\
\hline Casanova, A (\$2.3.3) & Granda, A (§2.2.4) \\
\hline Casas Novas, As (\$2.6.4) & Grañol (§2.6.14) \\
\hline Cedofeita $(\$ 2.2)$ & Guildeiros, Os (\$2.6.15) \\
\hline Cei $(\$ 2.1 .3)$ & Igrexa, A $(\$ 2.2 .5)$ \\
\hline Celeirós $(§ 2.4 .7)$ & Irexe $(\S 2.3 .7)$ \\
\hline Cepetal $(\$ 2.5 .5)$ & Lagar, O $(\S 2.5 .8)$ \\
\hline Cerdeiriñas, As (§2.3.4) & Liñeiro $(\S 2.5 .9)$ \\
\hline Chao de Ove, O (\$2.6.5) & Madanela, A (\$2.1.7) \\
\hline Cima de Vila (§2.1.4), (§2.3.5) & Maizán $(\S 2.3 .8)$ \\
\hline
\end{tabular}


Malatos, Os (\$2.6.16)

Marelle (\$2.4.9)

Meirengos $(\$ 2.5 .10)$

Mondigo, O (\$2.4.10)

Moural (\$2.3.9)

Noceda $(\$ 2.5 .11)$

Olleiros, Os $(\S 2.5 .12)$

Ove $(\$ 2.6)$

Palmeira, A (\$2.6.17)

Pastoriza (\$2.6.18)

Pedregal, O (\$2.2.6)

Pedreira, A (\$2.5.13)

Pega, A (§2.6.19)

Pereiriñas, As (§2.1.8)

Piñeiro $(\$ 2.2 .7)$

Ponte, A (§2.1.9), (§2.2.8), (§2.4.11)

Portobragán (§2.1.10)

Pousadoiro, O (\$2.4.12)

Preixoana, A (\$2.5.14)

Queixoiro (§2.2.9)

Rato, O (§2.5.15)

Rego de Mel (\$2.1.11)

Rego, O (\$2.3.10)

Reme (\$2.6.20)

Reme de Arriba (§2.4.13)

Remourelle (\$2.1.12)

Requiande (\$2.2.10)

Río de Ove, O (\$2.6.21)

Río de Ramos, O (\$2.6.22)

Río Pequeno, O (\$2.6.23)
Rochela, A (\$2.5.16)

$\mathrm{Sa}(\S 2.4 .14)$

Salcedo (\$2.4.15)

San Lázaro (\$2.6.24)

San Vicente (\$2.4.16)

Santa Cruz (2.6.25)

Santo Antonio (\$2.2.11)

Seixadelo (\$2.6.26)

Sendín (\$2.3.11)

Silveira, A (\$2.4.17)

Somo, O (\$2.4.18)

Teixido (\$2.2.12)

Torre, A (\$2.2.13)

Travesas de Ove, As (\$2.6.27)

Trapa, A (\$2.2.14)

Valín, O (\$2.6.28)

Veigadaira, A (\$2.6.29)

Venda, A (\$2.3.12)

Viladroiro, O (\$2.5.17)

Vilagoíz (§2.5.18)

Vilamariz (\$2.1.13)

Vilandriz (§2.5.19)

Vilar (\$2.6.30)

Vilar, O (\$2.4.19)

Vilavella, A (\$2.6.31)

Vilela $(\$ 2.4 .20)$

Volta, A (\$2.5.20)

Xardín, O (\$2.6.32)

Xunqueira, A (§2.3.13) 


\section{Bibliografía}

Aebischer, P. (1950): “'Salicetum' et 'salictum' dans les langues romanes”, Revista Portuguesa de Filologia 3: 70-85.

Álvarez Blanco, R. (2002): “Topónimos en -edo e -ido", en Boullón Agrelo, A. I. (ed.): Actas de XX Congreso Internacional de Ciencias Onomásticas (Santiago de Compostela, 20-25 de setembro de 1999): 87-101 (A Coruña: Pedro Barrié de la Maza).

Álvarez Maurín, M. P. (1994): Diplomática asturleonesa. Terminología toponímica (Ponferrada: Universidad de León).

Ares Vázquez, N. (1996): “Toponimia do concello do Saviñao”, Lucensia 13: 251272.

Baliñas Pérez, C. (1992): Do mito á realidade. A definición social e territorial de Galicia na Alta Idade Media (sécs. VIII e IX) (Santiago de Compostela: Coordenadas).

Bascuas López, E. (2000): "Rego y requeixo. Una pervivencia hispana de la raíz ind. er- "moverse"”, Verba 27: 359-378.

Bascuas López, E. (2001): “Mondoñedo y Valoría”, Estudios Mindonienses 17: 423-490.

Bascuas López, E. (2002): Estudios de hidronimia paleoeuropea gallega. Anexo 51 de Verba (Santiago de Compostela: Universidade de Santiago de Compostela).

Boullón Agrelo, A. I. (1999): Antroponimia medieval galega (ss. VII-XII) (Tübingen: Max Niemeyer Verlag).

Cal Pardo, E. (1999): Colección Diplomática Medieval do Arquivo da Catedral de Mondoñedo (Santiago de Compostela: Consello da Cultura Galega).

Coromines, J. (1949): "Duas etimologias portuguesas", Boletim de Filologia, t. 10: 334-340.

Crespo Pozo, J. S. (1985): Nueva contribución a un vocabulario castellano-gallego con indicación de fuentes e inclusión del gallego literario y galaico portugués (Sada: O Castro).

DCECH = Coromines, J. / Pascual, J. A. (1980-1991): Diccionario critico etimológico castellano e hispánico (Madrid: Gredos).

$D E L L=$ Ernout, A. / Meillet, A. (1985): Dictionnaire étymologique de la langue latine. Histoire des mots (Paris: L. Klincksieck). 
$D L G a$ = Feixó Cid, X.G. (coord.) (1986): Diccionario da lingua galega (Vigo: Ir Indo).

DLP = Houaiss, A. et al. (2001): Dicionário Houaiss da língua portuguesa (Rio de Janeiro: Objetiva).

$D N G=$ Ferro Ruibal, X. (dir.) (1992): Diccionario dos nomes galegos (Vigo: Ir Indo).

Dobarro Paz, J. M. (1974): Vocabulario de Capela (Cabalar). Tese de Licenciatura inédita (Santiago de Compostela: Universidade de Santiago de Compostela).

Fernandes, A. de Almeida (2001): Toponímia de Ponte de Lima (Ponte de Lima: Arquivo Ponte de Lima / Câmara Municipal de Ponte de Lima).

Ferreira Priegue, E. (1988): Los caminos medievales de Galicia. Anexo do Boletín Auriense 9 (Ourense: Museo Arqueolóxico Provincial).

Ferreiro Fernández, M. (1999): Gramática Histórica Galega (I. Fonética e Morfosintaxe) (A Coruña: Laiovento).

García Arias, X. L. (2000): Pueblos Asturianos el porqué de sus nombres (Xixón: Albora Llibros).

$H g N b=$ Piel, J.M. / Kremer, D. (1976): Hispano-gotisches Namenbuch. Der Niederschlag des Westgotischen in den alten und heutigen Personen und Ortsnamen der Iberichen Halbinsel (Heidelberg: Carl Winter).

Hubschmid, J. (1960): „Lenguas prerromanas no indoeuropeas. Testimonios románicos“, Enciclopedia lingüistica hispánica 1: 27-66.

IEW = Pokorny, J. (1959): Indogermanisches etymologisches Wörterbuch (Bern: Francke Verlag).

$L C=$ Kajanto, I. $\left(1982^{2}\right)$ : The Latin Cognomina (Roma: Giorgio Bretschneider Editore).

Ledo Cabido, B. (ed.) (2004): Dicionario de galego Ir Indo (Vigo: Ir Indo).

López Alsina, F. (1976): Introducción al fenómeno urbano medieval gallego, a través de tres ejemplos: Mondoñedo, Vivero y Ribadeo (Santiago de Compostela: Universidade de Santiago de Compostela).

Marqués Valea, X. (2004): A toponimia de Trabada (Santiago de Compostela: Xunta de Galicia).

Martínez Lema, P. (2010): Toponimia das comarcas de Bergantiños, Fisterra, Soneira e Xallas na documentación do Tombo de Toxos Outos (s. XII-XIV) (Santiago de Compostela: Universidade de Santiago de Compostela). 
Menéndez Pidal, R. (1968): Toponimia prerrománica hispana (Madrid: Gredos).

Moralejo Laso, A. (1977): Toponimia gallega y leonesa (Santiago: Pico Sacro).

Navaza Blanco, G. (2006): Fitotoponimia galega (A Coruña: Fundación Pedro Barrié de la Maza).

NDLEE = Miguel y Navas, R. de (1967): Nuevo diccionario latino-español etimológico (Madrid: Agustín Jubera).

$N L=$ Cañizares, B. (1992): "Nomenclátor toponímico medieval de la diócesis", Lucensia 5: 137-185.

Piel, J.M. (1945): “As águas na toponímia galego-portuguesa”, Boletim de Filologia 8, 4: 305-342.

Piel, J.M. (1948): Nomes de “possessores" latino-cristiãos na toponímia asturogalego-portuguesa (Coimbra: Universidade de Coimbra).

Piel, J.M. (1950): “Os nomes dos santos tradicionais hispânicos na toponimia peninsular", separata de Biblos vols. XXV-XXVI (Coimbra: Universidade de Coimbra).

Piel, J.M. (1984): "Novíssimas achegas à história da tradição antropotoponomástica mais antiga latina no Noroeste galaico", Verba 11: 5-24.

Piel, J.M. (1989): Estudos de lingüistica histórica galego-portuguesa ([Lisboa]: Imprensa Nacional / Casa da Moeda).

$R E W=$ Meyer-Lübke, W. (1972): Romanisches Etymologisches Wörterbuch (Heidelberg: Carl Winter. Universitätsuerlag).

Rivas Quintas, E. (1982): Toponimia de Marín, Anexo 18 de Verba (Santiago de Compostela: Universidade de Santiago de Compostela).

Rivas Quintas, E. (1991): Onomástica persoal do Noroeste hispano (Lugo: Alvarellos).

Rodríguez González, A. / Rey Caíña, J. A. (1992): “Tumbo de Lorenzana”, Estudios Mindonienses 8: 6-324.

Santamarina Fernández, A. (ed.) (2003): Diccionario de diccionarios [versión 3] (A Coruña: Fundación Pedro Barrié de la Maza).

- $\quad D E G C=$ Rodríguez González, E. (1958: 1961): Diccionario enciclopédico gallego-castellano, 3 vols (Vigo: Galaxia).

- $\quad D G C=$ Valladares Núñez, M. (1884): Diccionario gallego-castellano (Santiago de Compostela: Seminario C. Central). 
- $\quad D G C V=$ Carré Alvarellos, L. (1972 $)$ : Diccionario galego-castelán e vocabulario (A Coruña: Moret).

- Frampas II = Rivas Quintas, E. (1988): Frampas II: contribución al diccionario gallego (Salamanca: Editorial Ceme).

- $G V G=$ García, C. (1985): Glosario de Voces galegas de hoxe, anexo de Verba, 27 (Santiago de Compostela: Universidade de Santiago de Compostela).

- HERGP = Otero Álvarez, A. (1949): Hipótesis etimológicas referentes al gallego-portugués (Madrid: Cuaderno de Estudios Gallegos).

- $\quad V B O=$ Acevedo y Huelves, B. / Fernández y Fernández, M. (1932): Vocabulario del bable de occidente (Madrid: Centro de Estudios Históricos).

- $\quad V G=$ Sarmiento, M. (1975): Viaje a Galicia, en Pensado Tomé, J. L. (ed.) (Salamanca: Universidad de Salamanca).

- $\quad V P G C=$ Filgueira Valverde, X. et al. (1926): Vocabulario Popular GalegoCastelán (Santiago de Compostela: Seminario de Estudios Galegos).

Sanz Alonso, B. (1997): Toponimia de la provincia de Valladolid. Las cuencas del Duero, Pisuerga y Esgueva (Valladolid: Universidad de Valladolid).

TMILG = Varela Barreiro, X. (dir.) (2004-): Tesouro Medieval Informatizado da Lingua Galega (Santiago de Compostela: Instituto da Lingua Galega). [http:// ilg.usc.es/tmilg].

Varela Sieiro, X. (2008): Léxico cotián na Alta Idade Media de Galicia: arquitectura civil. Anexo 62 de Verba (Santiago de Compostela: Universide de Santiago de Compostela).

Vázquez Fernández, M. I. (1971): El habla y el léxico de Pereiramá (Lugo). Tese de licenciatura inédita (Santiago de Compostela: Universidade de Santiago de Compostela).

Vázquez Santamarina, M. E. (1971): El habla de La Gudiña. Tese de licenciatura inédita (Santiago de Compostela: Universidade de Santiago de Compostela).

Villar Liébana, F. (2000): Indoeuropeos y no indoeuropeos en la Hispania prerromana: las poblaciones y las lenguas prerromanas de Andalucía, Cataluña y Aragón según la información que nos proporciona la toponimia (Salamanca: Ediciones Universidad de Salamanca).

Xunta de Galicia (2003): Nomenclátor de Galicia. Dispoñíbel en <http: //www. xunta.es/toponimia> [consult. 19/12/2011]. 
